\title{
Available energy and energy balance closure at four coniferous forest sites across Europe
}

\author{
Uta Moderow • Marc Aubinet • Christian Feigenwinter • Olaf Kolle • \\ Anders Lindroth • Meelis Mölder • Leonardo Montagnani • Corinna Rebmann • \\ Christian Bernhofer
}

Received: 2 May 2008 / Accepted: 17 December 2008 / Published online: 26 July 2009

(C) Springer-Verlag 2009

\begin{abstract}
The available energy (AE), driving the turbulent fluxes of sensible heat and latent heat at the earth surface, was estimated at four partly complex coniferous forest sites across Europe (Tharandt, Germany; Ritten/Renon, Italy; Wetzstein, Germany; Norunda, Sweden). Existing data of net radiation were used as well as storage change rates calculated from temperature and humidity measurements to finally calculate the $\mathrm{AE}$ of all forest sites with uncertainty bounds. Data of the advection experiments MORE II (Tharandt) and ADVEX (Renon, Wetzstein, Norunda) served as the main basis. On-site data for referencing and
\end{abstract}

U. Moderow $(\bowtie) \cdot$ C. Bernhofer

Institute of Hydrology and Meteorology,

Department of Meteorology, Technische Universität Dresden, 01062 Dresden, Germany

e-mail: uta.moderow@forst.tu-dresden.de

M. Aubinet $\cdot$ C. Feigenwinter

Unité de Physique des Biosystèmes,

Faculté Universitaire des Sciences Agronomiques de Gembloux,

Gembloux, Belgium

O. Kolle $\cdot$ C. Rebmann

Max Planck Institute for Biogeochemistry,

Jena, Germany

A. Lindroth $\cdot$ M. Mölder

GeoBiosphere Centre, Physical Geography and Ecosystems

Analysis, University of Lund,

Lund, Sweden

L. Montagnani

Forest Service, Autonomous Province of Bolzano,

Bolzano, Italy

C. Feigenwinter

Institute of Meteorology, Climatology and Remote Sensing,

University of Basel,

Basel, Switzerland cross-checking of the available energy were limited. Applied cross checks for net radiation (modelling, referencing to nearby stations and ratio of net radiation to global radiation) did not reveal relevant uncertainties. Heat storage of sensible heat $J_{\mathrm{H}}$, latent heat $J_{\mathrm{E}}$, heat storage of biomass $J_{\text {veg }}$ and heat storage due to photosynthesis $J_{\mathrm{C}}$ were of minor importance during day but of some importance during night, where $J_{\text {veg }}$ turned out to be the most important one. Comparisons of calculated storage terms $\left(J_{\mathrm{E}}, J_{\mathrm{H}}\right)$ at different towers of one site showed good agreement indicating that storage change calculated at a single point is representative for the whole canopy at sites with moderate heterogeneity. The uncertainty in AE was assessed on the basis of literature values and the results of the applied cross checks for net radiation. The absolute mean uncertainty of $\mathrm{AE}$ was estimated to be between 41 and $52 \mathrm{~W} \mathrm{~m}^{-2}\left(10-11 \mathrm{~W} \mathrm{~m}^{-2}\right.$ for the sum of the storage terms $J$ and soil heat flux $G$ ) during mid-day (approximately $12 \%$ of $\mathrm{AE}$ ). At night, the absolute mean uncertainty of AE varied from 20 to about $30 \mathrm{~W} \mathrm{~m}^{-2}$ (approximately $6 \mathrm{~W} \mathrm{~m}^{-2}$ for $J$ plus $G$ ) resulting in large relative uncertainties as AE itself is small. An inspection of the energy balance showed an improvement of closure when storage terms were included and that the imbalance cannot be attributed to the uncertainties in AE alone.

\section{Introduction}

A formulation of the first law of thermodynamics, which states the conservation of energy, is the equation of the energy balance near the earth surface (Eq. 1). It can be written as follows:

$R_{\text {net }}-G-J=H+\mathrm{LE}$ 
where $R_{\text {net }}$ is the net radiation, $G$ the soil heat flux, $J$ the heat storage change in canopy air and biomass, $H$ the turbulent sensible heat flux and LE the turbulent latent heat flux. The left hand side of the equation represents the available energy (AE) that is redistributed by the turbulent fluxes $H$ and LE to the atmosphere. Positive turbulent fluxes are directed away from the earth surface whilst positive net radiation is directed towards the earth surface. Positive values of storage change indicate that energy is added to the storage and negative values of storage change indicate that energy is removed from the storage. Most of the different components of the energy balance are not measured at the earth surface directly. Therefore, a reference height some metres above the earth surface is chosen which in turn requires accounting for the storage term $J$ below this reference height. Note that Eq. 1 is valid under the assumption of zero advection only.

According to the conservation of energy, the energy balance at the earth surface should be closed. However, the energy balance is seldom closed when its components are measured in the field independently. This results in the socalled energy balance closure problem or lack of energy closure, i.e. the amount of available energy is not matched by the turbulent fluxes. There are numerous studies reporting a lack of energy closure (e.g. Aubinet et al. 2000; Barr et al. 1994, 2006; Bernhofer 1992; Bernhofer and Vogt 1999; Blanford et al. 1991; Blanken et al. 1998; Finch and Harding 1998; Jarvis et al. 1997; Kabat et al. 1997; Laubach 1996; Malhi et al. 2002; Oncley et al. 2007; Twine et al. 2000; Wilson et al. 2002; Wilson and Baldocchi 2000). Wilson et al. (2002) found an imbalance in the order of $20 \%$ for a number of FLUXNET sites. Smaller imbalances were found in homogenous terrain with little deviation from the 'ideal site requirement' (e.g. Grelle and Lindroth 1996; Heusinkveld et al. 2004; Mauder et al. 2007a).

Energy and mass fluxes are often measured by the eddycovariance method, which is widely used in describing and studying ecosystem exchanges with the atmosphere (Aubinet et al. 2000; Goulden et al. 1996; Pilegaard et al. 2001; Valentini et al. 1996; Valentini 2003). However, especially during nights with stable atmospheric stratification, fluxes are reported to be underestimated by this method (e.g. Aubinet et al. 2000; Aubinet 2008). In this context, advection is a highly discussed topic especially in relation to the net ecosystem exchange of $\mathrm{CO}_{2}$ (e.g. Aubinet et al. 2003; Baldocchi et al. 2000a; Feigenwinter et al. 2004; Lee 1998; Lee and $\mathrm{Hu}$ 2002; Paw U et al. 2000; Staebler and Fitzjarrald 2004). It is also suspected and discussed that advection may contribute to the lack of energy closure (e.g. Baldocchi and Rao 1995; Bernhofer 1992; Bernhofer and Vogt 1999; Blanford et al. 1991; Lee 1998; Lee and Hu
2002; Moderow et al. 2007; Paw U et al. 2000; Wilson et al. 2002). Therefore, it is important to determine the available energy as accurately as possible; otherwise, any evaluation of the importance of advection in relation to the energy balance will fail.

The final aim of this study was to achieve reliable uncertainty bounds of $\mathrm{AE}$ estimates and to evaluate the energy balance closure, at first, without considering advective fluxes that will form the basis for the ongoing investigation of the role of advective fluxes in the energy balance in further studies. Half-hourly data of the advection experiments ADVEX (Ritten/Renon (RE), Wetzstein (WS), Norunda (NO)) and MORE II (Tharandt, TH) were the basis to determine all relevant components of the available energy. This had to be done with a limited set of data for referencing and cross checking, as these experiments were primarily designed for a careful evaluation of the $\mathrm{CO}_{2}$ balance including advection (Feigenwinter et al. 2008).

\section{Sites and instrumentation}

\subsection{Sites}

All investigated sites have been part of the European carbon and water flux programme of CarboEurope-Integrated Project (IP). Ritten/Renon (Italy), Wetzstein (Germany) and Norunda (Sweden) were sites of the experimental campaign ADVEX (Feigenwinter et al. 2008) of CarboEurope-IP in 2005 and 2006, respectively. A similar experiment took place at Tharandt (Germany) in 2003, called MORE II (More measurements in the ORE Mountains). Both experiments targeted to capture advective fluxes of $\mathrm{CO}_{2}$. Main characteristics of these sites are presented in Table 1 and references with more detailed descriptions of the sites are given too.

\subsection{Instrumentation}

The description of the experimental setup and instrumentation will be restricted to issues relevant to this study. More information about MORE II (TH) can be found in Moderow et al. (2007). Feigenwinter et al. (2008) give a detailed description of the ADVEX measurement scheme in RE, WS and NO. An overview of the most relevant instrumentation is given in Table 2. Figure 1 shows the main points of the two different setups. Three additional towers (P1, P2, P3) were erected for MORE II to capture advective fluxes. However, we focussed on the measurements of the main tower as the profile of air temperature and humidity was most dense here. Four additional towers (A, B, C, D) were used during the ADVEX experiments. A 
Table 1 Main characteristics of the investigated sites

\begin{tabular}{|c|c|c|c|c|}
\hline & $\mathrm{TH}$ & $\mathrm{RE}$ & WS & NO \\
\hline Region & Ore Mountains & Italian Alps & Thuringia & Uppland \\
\hline Latitude & $50^{\circ} 58 \mathrm{~N}$ & $46^{\circ} 35 \mathrm{~N}$ & $50^{\circ} 27 \mathrm{~N}$ & $60^{\circ} 05 \mathrm{~N}$ \\
\hline Longitude & $13^{\circ} 34 \mathrm{E}$ & $11^{\circ} 26 \mathrm{E}$ & $11^{\circ} 27 \mathrm{E}$ & $17^{\circ} 28 \mathrm{E}$ \\
\hline Elevation $(\mathrm{m})$ & 385 & 1,735 & 782 & 45 \\
\hline Topography & Hilly & Slope & Mountain crest & Flat \\
\hline Main species & Picea abies & $85 \%$ Picea abies & Picea abies & $\begin{array}{l}\text { Picea abies } \\
\text { Pinus sylvestris }\end{array}$ \\
\hline Stand age (a) & 115 & Uneven & 55 & $50-100$ \\
\hline $\begin{array}{l}\text { Tree density } \\
\left(\mathrm{ha}^{-1}\right)\end{array}$ & 477 (year 2002) & $270(\mathrm{DBH}>12 \mathrm{~cm}$, year 2000$)$ & 670 & $600($ year 2000) \\
\hline $\begin{array}{l}\text { Canopy height } \\
\text { (m) }\end{array}$ & 30 & $20-30$ & 20 & 25 \\
\hline \multirow{2}{*}{$\begin{array}{l}\text { Investigated } \\
\text { period }\end{array}$} & DOY 185-285 & DOY $178-258$ & DOY $102-170$ & DOY 188-261 \\
\hline & Year 2003 & Year 2005 & Year 2006 & Year 2006 \\
\hline \multirow[t]{2}{*}{ References } & Grünwald (2002) & Marcolla et al. (2005) & Anthoni et al. (2004) & Lundin et al. (1999) \\
\hline & $\begin{array}{l}\text { Grünwald and Bernhofer } \\
\text { (2007) }\end{array}$ & $\begin{array}{l}\text { L. Montagnani, personal } \\
\text { communication }\end{array}$ & $\begin{array}{l}\text { C. Rebmann, personal } \\
\text { communication }\end{array}$ & $\begin{array}{l}\text { M. Mölder, personal } \\
\text { communication }\end{array}$ \\
\hline
\end{tabular}

TH Tharandt, RE Ritten/Renon, WS Wetzstein, NO Norunda, DOY day of the year, $D B H$ diameter at breast height

vertical profile of four measurements points (water vapour, air temperature) is available at these towers giving the opportunity to compare estimates of storage terms of different locations.

\section{Materials and methods}

\subsection{Net radiation}

Net radiation is the main component of the energy balance and is the sum of shortwave net radiation $R_{\mathrm{sw}}{ }^{*}$ and longwave net radiation $R_{\mathrm{lw}}{ }^{*}$.

$R_{\mathrm{net}}=R_{\mathrm{sw}} \downarrow-R_{\mathrm{sw}} \uparrow+R_{\mathrm{lw}} \downarrow-R_{\mathrm{lw}} \uparrow=R_{\mathrm{SW}} *+R_{\mathrm{lw}} *$

where $R_{\mathrm{sw}} \downarrow$ denotes downwards shortwave radiation and $R_{\mathrm{sw}} \uparrow$ upwards shortwave radiation, $R_{\mathrm{lw}} \downarrow$ downward longwave radiation and $R_{\mathrm{lw}} \uparrow$ upwards longwave radiation.

The measurement of net radiation has been subject of several studies (e.g. Brotzge and Duchon 2000; Duchon and Wilk 1994; Field et al. 1992; Halldin and Lindroth 1992; Kohsiek et al. 2007; Vogt et al. 1996; Vogt 2000). The evaluation of the accuracy of the net radiation measurements is complicated as there is no accepted standard for net radiation measurements (e.g. Kohsiek et al. 2007; Vogt et al. 1996). More recently, it was recommended to measure the individual components separately (Brotzge and Duchon 2000; Halldin 2004; Kohsiek et al. 2007).

A four component system (CNR1, Kipp \& Zonen) is used at RE and WS matching the aforementioned recommendation. Net radiation is measured by a net radiometer (Schulze-Däke type) at TH and NO. Net radiation could be referenced to independent measurements of the four individual components at $\mathrm{TH}$ (following a procedure as found in, e.g. Vogt et al. 1996).

All investigated net radiometers are regularly maintained (visual inspection, cleaning, changing of domes if necessary) although at different intervals. The CNR1 of WS and RE were calibrated in 2001, i.e. 5 and 4 years before the ADVEX experiments, respectively. The net radiometers of the Schulze-Däke type of TH and NO were calibrated in 1997 and 1998, i.e. 6 and 8 years before the corresponding advection experiment, respectively.

As the experiments ADVEX and MORE II were not explicitly designed for the investigation of the energy balance, we did not have any means to check the accuracy of $R_{\text {net }}$ directly. However, we performed some simple tests to check for gross errors in the available measurements of net radiation at least and focussed on shortwave radiation as the main component of net radiation. First global radiation (hourly daytime values) was modelled for selected clear sky days using the radiative transfer model Streamer (Key 2001). All simulations were done for cloudless conditions using a standard profile of the atmosphere optimised for mid-latitude summer combined 
Table 2 Main instrumentation and measurements (only study-relevant instrumentation and measurements are listed)

\begin{tabular}{|c|c|c|c|c|}
\hline & $\mathrm{TH}$ & $\mathrm{RE}$ & WS & NO \\
\hline \multicolumn{5}{|l|}{ Air temperature } \\
\hline Instrument & Thermocouple $^{\mathrm{a}}$ & Thermocouple $^{\mathrm{a}}$ & Thermocouple $^{\mathrm{a}}$ & Thermocouple $^{\mathrm{a}}$ \\
\hline Height (m) & $\begin{array}{l}0.5,2,8,18,26,33 \\
\text { main tower }\end{array}$ & $\begin{array}{l}1.5,6,12,30 \text { at towers } \\
\text { A, B, C, D }\end{array}$ & $\begin{array}{l}1.5,4.4,8.8,24 \text { at towers } \\
\text { A, B, C, D }\end{array}$ & $\begin{array}{l}1.5,6,12,30 \text { at towers } \\
\text { A, B, C, D }\end{array}$ \\
\hline \multicolumn{5}{|l|}{$\mathrm{H}_{2} \mathrm{O}$ - profile } \\
\hline Instrument & $\operatorname{Li~} 6262^{\mathrm{b}}$ & $\operatorname{Li} 6262 / 7000^{\mathrm{b}}$ & Li $6262 / 7000^{\mathrm{b}}$ & $\operatorname{Li} 6262^{\mathrm{b}}$ \\
\hline Height (m) & $\begin{array}{l}0.5,2,8,26,33,37 \\
\text { main tower }\end{array}$ & $\begin{array}{l}1.5,6,12,30 \text { at towers } \\
\text { A, B, C, D }\end{array}$ & $\begin{array}{l}1.5,4.4,8.8,24 \text { at towers } \\
\text { A, B, C, D }\end{array}$ & $\begin{array}{l}1.5,6,12,30 \text { at towers } \\
\text { A, B, C, D }\end{array}$ \\
\hline \multicolumn{5}{|c|}{ Biomass temperature } \\
\hline Instrument & $\begin{array}{l}\text { Thermocouple }{ }^{\mathrm{c}} \\
(4 \times \text { bole, } 2 \times \text { bark })\end{array}$ & Thermocouple $^{\mathrm{c}}(2 \times$ bole $)$ & PT100 $(10 \times$ bole $)$ & Thermocouple $(11 \times$ bole $)$ \\
\hline Height (m) & $1.5,16$ & 1.3 & 1.5 & $1.2-10.7$ \\
\hline Depth (m) & 0.08 (bole), 0.01 (bark) & Bole & 0.05 , centre of tree & $0.07,0.03$ \\
\hline Tree & Picea abies & Picea abies & Picea abies & Picea abies, Pinus sylvestris \\
\hline \multicolumn{5}{|l|}{ Radiation } \\
\hline Net radiation & Schulze-Däke ${ }^{\mathrm{d}}$ & $\mathrm{CNR} 1^{\mathrm{g}}$ & $\mathrm{CNR} 1^{\mathrm{g}}$ & Schulze-Däke ${ }^{\mathrm{d}}$ \\
\hline Height (m) & 37 & 38 & 30 & 68 \\
\hline Global radiation & $\mathrm{CM} 7^{\mathrm{e}}$ & $\mathrm{CM}^{\mathrm{g}}$ (part of CNR1) & $\mathrm{CM}^{\mathrm{g}}$ (part of CNR1) & $\mathrm{CM} 21^{\mathrm{g}}$ \\
\hline Height (m) & 37 & 38 & 30 & 102 \\
\hline \multicolumn{5}{|l|}{ Soil heat flux } \\
\hline Heat flux plate & $\operatorname{PLE}^{\mathrm{f}}$ (2 plates) & HFP01SC ${ }^{\text {h }}$ (2 plates) & $\mathrm{HP} 3 / \mathrm{CN} 3^{\mathrm{i}}$ (5 plates) & HFT $-1^{\mathrm{k}}$ ( 3 plates $)$ \\
\hline Depth (m) & $0.01-0.02$ & 0.05 & $0.02-0.03$ & 0.06 \\
\hline \multicolumn{5}{|l|}{ Soil temperature } \\
\hline Instrument & $\mathrm{PT} 100^{\mathrm{c}}$ & STP-01 ${ }^{\mathrm{h}}$ (PT100) & PT100 & Thermocouple $^{j}$ \\
\hline Depth (m) & $0.02,0.1,0.2$ & $0.05,0.1,0.2$ & $0.02,0.08,0.16$ & $0.05,0.1,0.2$ \\
\hline
\end{tabular}

TH Tharandt, RE Ritten/Renon, WS Wetzstein, NO Norunda

${ }^{a}$ Campbell, Sci., Logan, US, type E, diameter $0.75 \mu \mathrm{m}$

${ }^{\mathrm{b}}$ LiCor, Lincoln, NE, USA

${ }^{\mathrm{c}}$ Manufacturer not specified

${ }^{\mathrm{d}}$ Dr. Bruno Lange, Germany

${ }^{\mathrm{e}}$ Wilh. Lambrecht, Germany

${ }^{\mathrm{f}}$ Laborelektronik Ing. Peter Leskowa, Austria

${ }^{\mathrm{g}}$ Kipp \& Zonen, The Netherlands

${ }^{\mathrm{h}}$ Hukseflux, The Netherlands

${ }^{\mathrm{i}} \mathrm{McVan}$ Instruments, Australia (distributed by Thies Clima GmbH \& Co. KG, Germany)

${ }^{j}$ In Situ, Ockelbo, Sweden

${ }^{\mathrm{k}}$ REBS, Seattle, WA, USA

with a rural standard model of aerosols. In a second step, the measurements of global radiation (mean daily values) were compared with global radiation of nearby stations, and thirdly, the ratio (half-hourly values) of net radiation $R_{\text {net }}$ to global radiation RG was inspected for daytime conditions as net radiometers are primarily calibrated in the shortwave band. Data pairs with global radiation $\leq 5 \mathrm{~W} \mathrm{~m}^{-2}$ were excluded for this purpose. Information found in the literature (Halldin and Lindroth 1992; Kohsiek et al. 2007) was included to determine uncertainty bounds for net radiation.

\subsection{Ground heat flux}

Equation 3 describes the ground heat flux including storage of heat between depth $z$ and soil surface.

$G=G_{Z}+G_{\mathrm{S}}=G_{Z}+C_{\mathrm{s}} \frac{\delta T_{\mathrm{s}}}{\delta t} \Delta z$

where $G$ is the soil heat flux at the soil surface, $G_{Z}$ is the measured heat flux at depth $z$ and $G_{\mathrm{S}}$ denotes the storage change between depth $z$ and soil surface, where $C_{\mathrm{s}}$ is the volumetric heat capacity of the soil, $T_{\mathrm{s}}$ the average soil 


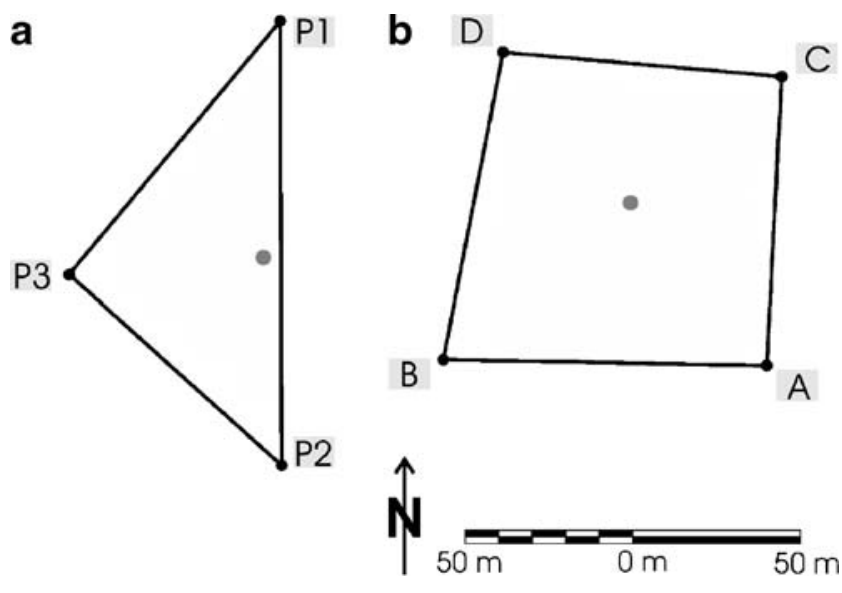

Fig. 1 a Schematic layout of MORE II. b Schematic layout of the general setup of the ADVEX experiments, example of Norunda. Grey circle denotes main tower and black circles denote additionally installed towers. Only study-relevant setup is shown

temperature of the layer between depth $z$ and soil surface and $t$ denotes time.

The chosen approach is a combination of two methods. The soil heat flux $G_{Z}$ is measured by heat flux plates at depth $z$, and calorimetry is used to account for the storage between the heat flux plate and soil surface. This combination of methods is expected to perform well, if the heat flux plates are installed deep enough (e.g. Mayocchi and Bristow 1995; Liebethal et al. 2005). Heat flux plates alone are often reported to underestimate the ground heat flux and the importance of $G_{\mathrm{S}}$ is underlined (e.g. Mayocchi and Bristow 1995; Ochsner et al. 2007; Sauer et al. 2003). However, most of the studies were performed at agricultural sites or sites with bare ground where the soil heat flux is quite large compared to forest sites, but soil heat flux under almost complete crown cover is regarded to be small due to smaller shortwave fluxes and reduction by litter (e.g. Baldocchi et al. 2000b; Garratt 1992).

Ground heat flux $G_{Z}$ is routinely measured by heat flux plates inserted only a few centimetres below the soil surface (Table 2) at all sites of this study. The average of the heat flux plates at each site was used to capture effects of soil heterogeneity and variable sun spots to some degree.

As information about soils was limited, a simplified approach was chosen to account for $G_{\mathrm{S}}$ using published values of $C_{\mathrm{s}}$ and estimated soil temperatures between soil surface and heat flux plate. Linearly extrapolated temperatures from measured temperatures at some deeper depths (Table 2) were used to estimate temperatures at following depth $0.03 \mathrm{~m}$ (RE, NO), $0.01 \mathrm{~m}$ (TH) and $0.02 \mathrm{~m}$ (WS). Use of linearly extrapolated temperature causes that time shift and damping of temperature with depth cannot be reproduced correctly. However, as the storage term $G_{\mathrm{S}}$ is expected to be small, this effect is expected to have a small impact. $C_{\mathrm{s}}$ was taken as constant with a value of
$1.7010^{6} \mathrm{~J} \mathrm{~m}^{-3} \mathrm{~K}^{-1}$ which corresponds to a wet but not saturated sandy soil with a pore space of approximately $40 \%$ (Oke 1987). This is a crucial point because $C_{\mathrm{s}}$ changes with changing soil moisture considerably. Thus in this approach, $G_{\mathrm{S}}$ is overestimated for drier conditions and underestimated for wetter conditions. Additionally, $G_{\mathrm{S}}$ obtained as described above was compared to $G_{\mathrm{S}}$ calculated using the soil temperature measured closest to the soil surface (Table 2) instead of extrapolated temperature.

\subsection{Heat storage change in canopy air and biomass}

The storage term $(J)$ due to storage in canopy air and biomass can be written as follows (Bernhofer et al. 2003):

$J=J_{\mathrm{H}}+J_{\mathrm{E}}+J_{\mathrm{veg}}+J_{\mathrm{C}}$

where $J_{\mathrm{H}}$ and $J_{\mathrm{E}}$ denote sensible heat storage change and latent heat storage change in the canopy air, $J_{\text {veg }}$ storage changes due to changes in biomass temperature and $J_{\mathrm{C}}$ storage changes due to photosynthetic activity. As storage terms become small for daily sums, they are often neglected for longer integration periods. Despite small magnitudes of most storage terms, several studies report a decrease in the imbalance of the energy budgets if storage is included (Aston 1985; Gu et al. 2007; McCaughey et al. 1997; Meyers and Hollinger 2004; Wilson et al. 2002). Therefore, storage terms should be carefully estimated.

\subsubsection{Sensible heat storage change $J_{H}$}

This storage term is caused by temperature changes in the canopy air and can be evaluated according to Eq. 5 .

$J_{\mathrm{H}}=\int_{0}^{z_{\mathrm{r}}} \rho_{\mathrm{a}}\left(T_{\mathrm{a}}\right) c_{\mathrm{p}} \frac{\delta T_{\mathrm{a}}}{\delta t} d z$

where $\rho_{\mathrm{a}}$ is air density, $T_{\mathrm{a}}$ air temperature and $c_{\mathrm{p}}$ specific heat capacity of air at constant pressure.

Four levels of air temperature measurements were available at RE, WS and NO and six levels at TH (Table 2). The thicknesses of the resulting layers were not constant amongst the sites as the reference height $z_{\mathrm{r}}$ (height of net radiometer) changes with site (Table 2). Differing from that, the height of flux measurement level at the main tower $(33 \mathrm{~m})$ was chosen for the Swedish site as reference height, because the height of net radiation measurement $(68 \mathrm{~m})$ differed from the height of the flux measurement $(33 \mathrm{~m})$ considerably. Storage change was calculated for each layer and summed up in order to obtain total storage change for every half hour.

$J_{\mathrm{H}} \cong \rho_{\mathrm{a}} c_{\mathrm{p}} \sum_{i=1}^{i=n}\left(\frac{\Delta T_{\mathrm{a}, i}}{\Delta t} \Delta z_{i}\right)$ 
where $i$ is the index of the respective layer and $\Delta z$ the layer thickness. This procedure might give larger maximum and minimum values in relation to a calculation procedure using only one level (Moderow et al. 2007). Air density $\rho_{\mathrm{a}}$ and specific heat capacity of air $c_{\mathrm{p}}$ is assumed to be constant over the whole canopy layer, following former studies (e.g. McCaughey 1985; Oliphant et al. 2004).

Below, an average of the different tower locations at RE, WS and NO is used for $J_{\mathrm{H}}$ as well as for $J_{\mathrm{E}}$.

\subsubsection{Latent heat storage change $J_{E}$}

Equation 7 gives the storage change of latent heat in the canopy air.

$J_{\mathrm{E}}=\int_{0}^{z_{\mathrm{r}}} L\left(T_{\mathrm{a}}\right) \frac{\delta \rho_{\mathrm{v}}}{\delta t} d z$

Here, $L\left(T_{\mathrm{a}}\right)$ denotes latent heat of vaporisation as a function of air temperature and vapour density $\rho_{\mathrm{v}}$. The storage change of latent heat was calculated in the same way as $J_{\mathrm{H}}$.

$J_{E} \cong L\left(T_{a}\right) \sum_{i=1}^{i=n}\left(\frac{\Delta \rho_{v, i}}{\Delta t} \Delta z_{i}\right)$

where the latent heat of vaporisation is assumed to be constant over the whole canopy. Usually $J_{\mathrm{E}}$ is calculated for the whole canopy using one measurement of humidity at a representative level in the canopy (e.g. McCaughey 1985; McCaughey and Saxton 1988; Moore and Fisch 1986; Vogt et al. 1996) and only few studies use more than one measurement level (e.g. Oliphant et al. 2004).

For reasons of consistency, $J_{\mathrm{E}}$ was calculated in the same way as $J_{\mathrm{H}}$ on half-hourly basis, i.e. a four-layer approach for RE, WS and NO and six layer approach for TH.

\subsubsection{Biomass heat storage change $J_{\text {veg }}$}

This term often receives less attention as it is small (at least for low canopies) and more extensive measurements as well as information about the structure of the canopy are necessary. Equation 9 gives the formula of $J_{\mathrm{veg}}$.

$J_{\mathrm{veg}}=\int_{0}^{z_{\mathrm{r}}} \rho_{\mathrm{veg}} c_{\mathrm{veg}} \frac{\delta T_{\mathrm{veg}}}{\delta t} d z$

where $\rho_{\mathrm{veg}}$ is the density of vegetation in kilogram per cubic metre, $T_{\text {veg }}$ biomass temperature and $c_{\text {veg }}$ canopyspecific heat capacity in Joule per kilogram per Kelvin.

Bole temperatures and information about wet biomass were available for all sites of this study, but no detailed information about the contributions of boles, branches or foliage and their temperatures for every site; therefore, $\mathrm{J}_{\mathrm{veg}}$ was calculated on a half-hourly basis in the following way:

$J_{\mathrm{veg}}=m_{\mathrm{veg}} c_{\mathrm{veg}} \frac{\Delta \overline{T_{\mathrm{veg}}}}{\Delta t}$

Here, $m_{\mathrm{veg}}$ denotes wet biomass mass in kilogram per square metre and $\Delta \overline{T_{\text {veg }}}$ the average biomass temperature. The average of the bole temperatures as listed in Table 2 were used to estimate $\Delta \overline{T_{\text {veg }}}$ for each site. A critical point of this procedure is that variations of temperatures in the different parts of the canopy are not adequately represented and corresponding time lags are blurred. Therefore, we also tested air temperature measured just above the canopy (at $30 \mathrm{~m} \mathrm{TH}, \mathrm{RE}, \mathrm{NO}$; at $24 \mathrm{~m} \mathrm{WS}$ ) as a proxy for biomass temperature (e.g. Gay et al. 1996).

A careful estimation of wet biomass is indicated because this parameter can easily change the magnitude of $J_{\text {veg }}$ (Eq. 10). Table 3 gives wet biomass for each site as used in the calculation. It should be kept in mind that the magnitude of wet biomass is influenced by the method used for estimation. Additionally, one estimate of wet biomass cannot reflect the situation throughout a heterogeneous canopy, despite a careful selection of a representative sample. Thus, the wet biomass already bears an uncertainty

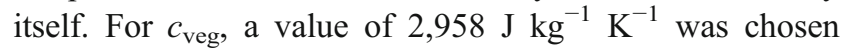
which was used in several studies (e.g. McCaughey 1985; McCaughey and Saxton 1988; Oliphant et al. 2004) following Thom (1975) that $c_{\mathrm{veg}}$ is approximately $70 \%$ of the corresponding value for water.

\subsubsection{Biochemical heat storage change $J_{C}$}

Radiation energy is absorbed during the process of photosynthesis by plants at daytime according to

$6 \mathrm{CO}_{2}+12 \mathrm{H}_{2} \mathrm{O} \stackrel{\text { light }}{\longrightarrow} \mathrm{C}_{6} \mathrm{H}_{12} \mathrm{O}_{6}+6 \mathrm{H}_{2} \mathrm{O}+6 \mathrm{O}_{2}$

whereupon an amount of $2,872 \mathrm{KJ}$ per mole glucose is fixed (Richter 1988). To account for this energy, half-hourly data of gross primary productivity (GPP) were used to calculate $J_{\mathrm{C}}$ following an approach of Laubach (1996) but replaced net ecosystem exchange of $\mathrm{CO}_{2}$ by GPP:

$J_{\mathrm{C}}=-\mu \mathrm{GPP}$

where $\mu$ is the specific energy of conversion due to photosynthesis $\left(10.88 \times 10^{6} \mathrm{~J}\right.$ per $\mathrm{kg}$ of $\left.\mathrm{CO}_{2}\right)$. Available GPP data $(\mathrm{TH})$ were used or GPP was calculated (RE, WS, NO) on the basis of the vertical turbulent flux of $\mathrm{CO}_{2}$ and storage change of $\mathrm{CO}_{2}$ using the online gap-filling and partitioning tool developed by Markus Reichstein ${ }^{1}$ (Reichstein et al.

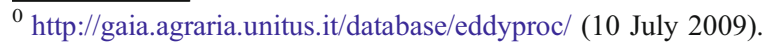


Table 3 Wet biomass of investigated sites

\begin{tabular}{|c|c|c|c|c|}
\hline & Tharandt & Ritten/Renon & Wetzstein & Norunda \\
\hline$m_{\mathrm{veg}}\left(\mathrm{kg} \quad \mathrm{m}^{-2}\right)$ & 39.85 (2001) & $39.22^{\mathrm{a}}(2005)$ & $39.18^{\mathrm{b}}(2002)$ & $47.5^{\mathrm{a}}(2006)$ \\
\hline Reference & $\begin{array}{l}\text { T. Grünwald, personal } \\
\text { communication }\end{array}$ & $\begin{array}{l}\text { L. Montagnani, personal } \\
\text { communication }\end{array}$ & $\begin{array}{l}\text { J. Schumacher, personal } \\
\text { communication }\end{array}$ & $\begin{array}{l}\text { F. Lagergren, personal } \\
\text { communication }\end{array}$ \\
\hline
\end{tabular}

${ }^{\mathrm{a}}$ Information about dry biomass has been provided. Dry weight is about $40-60 \%$ of fresh weight (B. Köstner, personal communication); therefore, a factor of 2 was chosen in order to estimate wet weight

${ }^{\mathrm{b}}$ Biomass estimate is based on estimates for aboveground biomass in grams of carbon per square metre. To convert into wet biomass, a factor of 2 was chosen

2005). Note that the accuracy of $J_{\mathrm{C}}$ relies on the quality of GPP data.

Some of the energy fixed by photosynthesis is steadily released by respiration and is already accounted for in sensible heat storage change $J_{\mathrm{H}}$ and heat storage change of biomass $J_{\text {veg }}$ (Blanken et al. 1997; Oncley et al. 2007). $J_{\mathrm{C}}$ adds energy to the storage and should be therefore positive during day and is zero during periods without photosynthesis, i.e. at night. Negative values of $J_{\mathrm{C}}$ as well as positive values of $J_{\mathrm{C}}$ during night were considered as erroneous and were removed $(<4 \%$ of all half-hourly values, mostly during transition periods).

\section{Results}

\subsection{Radiation}

None of the performed simple tests (described in Section 3.1) revealed large errors in radiation measurements; however, they did not allow to define any uncertainty ranges, and therefore, it is refrained from presenting the results more in detail. Information found in literature was used to estimate the uncertainty ranges. The applied net radiometer types have been subject of several inter-comparison studies (Brotzge and Duchon 2000; Halldin and Lindroth 1992; Kohsiek et al. 2007; Vogt et al. 1996). The Schulze-Däke type was investigated by Halldin and Lindroth (1992). It performed well almost within the accuracy of their reference net radiation that was $\pm 3.5 \%$ and $\pm 10 \mathrm{~W} \mathrm{~m}^{-2}$ (whichever was the largest). Kohsiek et al. (2007) found that CNR1 and Schulze-Däke yielded similar values (within $20 \mathrm{~W} \mathrm{~m}^{-2}$ ) like the reference sum of four components.

Taking the findings of Kohsiek et al. (2007) as well as Halldin and Lindroth (1992) into consideration, a quite pragmatic estimate was chosen. The uncertainty in net radiation was evaluated to be $\pm 7 \%$ or $\pm 20 \mathrm{~W} \mathrm{~m}^{-2}$, which correspond not only to the doubled accuracy bounds for the Schulze-Däke as reported by Halldin and Lindroth (1992) but also to the absolute uncertainty as reported by Kohsiek et al. (2007). This estimate was then slightly enlarged to account for the fact that the net radiation measurements could not be compared to a reference. Therefore, the uncertainty bound for all sites was estimated to be $\pm 8 \%$ or $\pm 23 \mathrm{~W} \mathrm{~m}^{-2}$ (whichever was the largest).

\subsection{Ground heat flux}

The inspection of the ground heat fluxes $G_{Z}$ did not reveal any hint for large errors for any of the sites. The measurements of the different heat flux plates used to calculate the final ground heat flux $G_{Z}$ were compared with each other. In general, they reflected the expected heterogeneity of ground heat flux below a heterogeneous canopy quite well (except for the site with only two heat flux plates) and the average of the measurements of these heat flux plates were taken as a good approximation for the true mean value of ground heat flux at the respective site. Changes between shade and sun were more apparent for sites with very shallow inserted heat flux plates (TH, WS) and maxima were shifted towards late afternoon (Fig. 2) for deeper installed heat flux plates (RE, NO). Mean values (Table 5) of $G_{Z}$ were positive due to the fact that the experiments took place during the warm season mainly. The mean daily variation was clearly changed if $G_{\mathrm{S}}$ was added to $G_{Z}$. The maximum was shifted towards the morning hours and the amplitudes were increased. The mean value of $G$ over the whole experimental period was only slightly changed (Table 5) if $G_{\mathrm{S}}$ was included. $G_{\mathrm{S}}$ was positive at WS as a period in spring and early summer was investigated and heat was added to the soil.

$G_{\mathrm{S}}$ was also estimated using soil temperature measured closest to the soil surface (Table 2) and resulted in almost identically mean values. However, the scatter was enlarged and the daily maximum was shifted towards the morning. The latter one is more physical as the extrapolated temperatures were obtained without consideration of any time shift.

The relative size of $G_{Z}$ and $G_{\mathrm{S}}$ in relation to $R_{\text {net }}$ was evaluated on the basis of the mean diurnal variation of both terms (Fig. 3). It should be noted that during transition periods, $G_{\mathrm{S}}, G_{Z}$ and $R_{\text {net }}$ are small quantities and the latter 

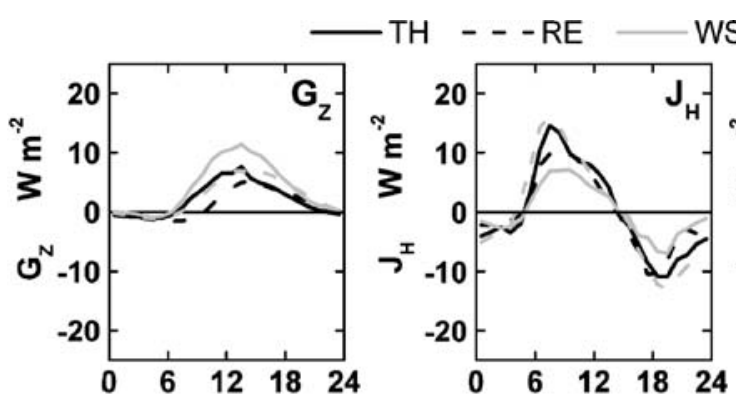

WS $\ldots$ NO
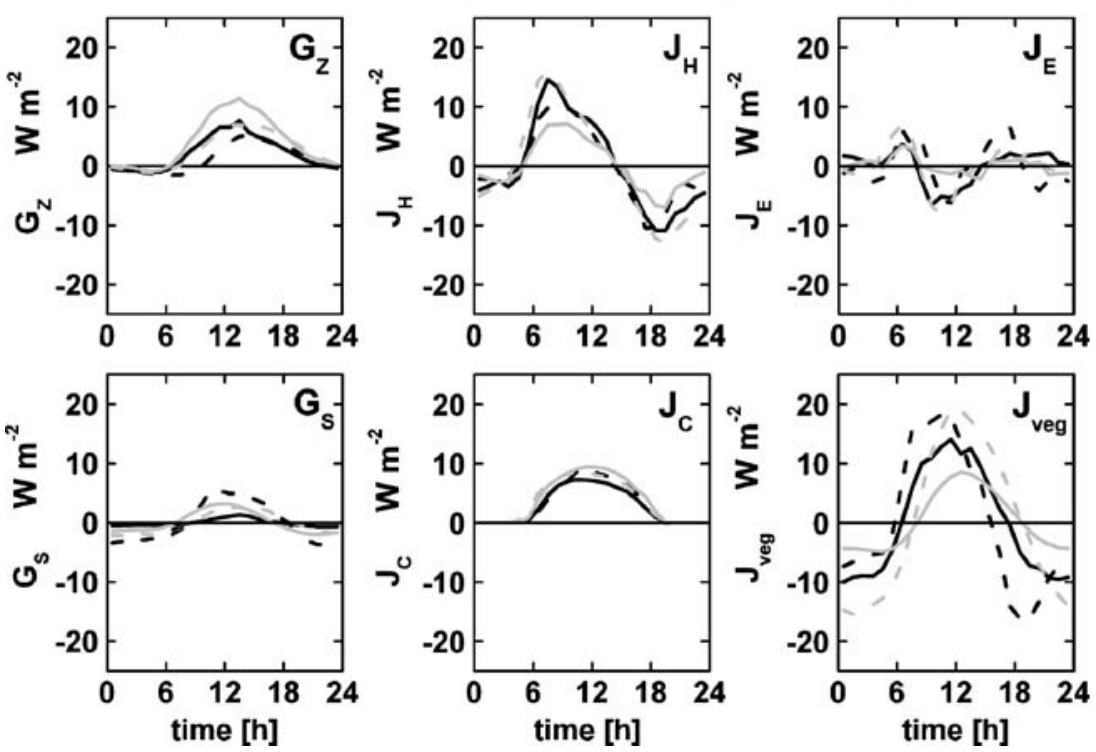

Fig. 2 Mean diurnal courses of $G_{Z}$ and of the storage terms $G_{\mathrm{S}}, J_{\mathrm{H}}$, $J_{\mathrm{E}}, J_{\mathrm{veg}}$ and $J_{\mathrm{C}}(1-\mathrm{h}$ averages) averaged over the investigated period of each experiment (Table 1). Error bars denoting standard deviations

were omitted for clarity. Standard deviation was clearly less than $10 \mathrm{~W} \mathrm{~m} \mathrm{~m}^{-2}$ for $G_{Z}, G_{\mathrm{S}}$ and $J_{\mathrm{C}}$ and approximately between 5 and $20 \mathrm{~W} \mathrm{~m}^{-2}$ for $J_{\mathrm{H}}, J_{\mathrm{E}}$ and $J_{\mathrm{veg}}$

one also changes its sign. Thus, a determination of a ratio may prone to be erroneous, as absolute values are small, and additionally, these terms are not necessarily in phase. This also holds for the energy balance terms discussed in the following: During day, the relative size of $G_{\mathrm{S}}(\approx 1 \%)$ was smaller than that of $G_{Z}(\leq 3 \%)$, but exceeded it with values up to $8 \%$ at night. This indicates that $G_{\mathrm{S}}$ might be of some importance at least during night. However, an importance of $G_{\mathrm{S}}$, as reported for agricultural sites (e.g. Mayocchi and Bristow 1995; Ochsner et al. 2007; Sauer et al. 2003), was not found. For example, Mayocchi and Bristow (1995) reported errors up to $80 \mathrm{~W} \mathrm{~m}^{-2}$ for a sugarcane field if $G_{\mathrm{S}}$ was neglected, but gave no relative size in relation to $R_{\text {net }}$.
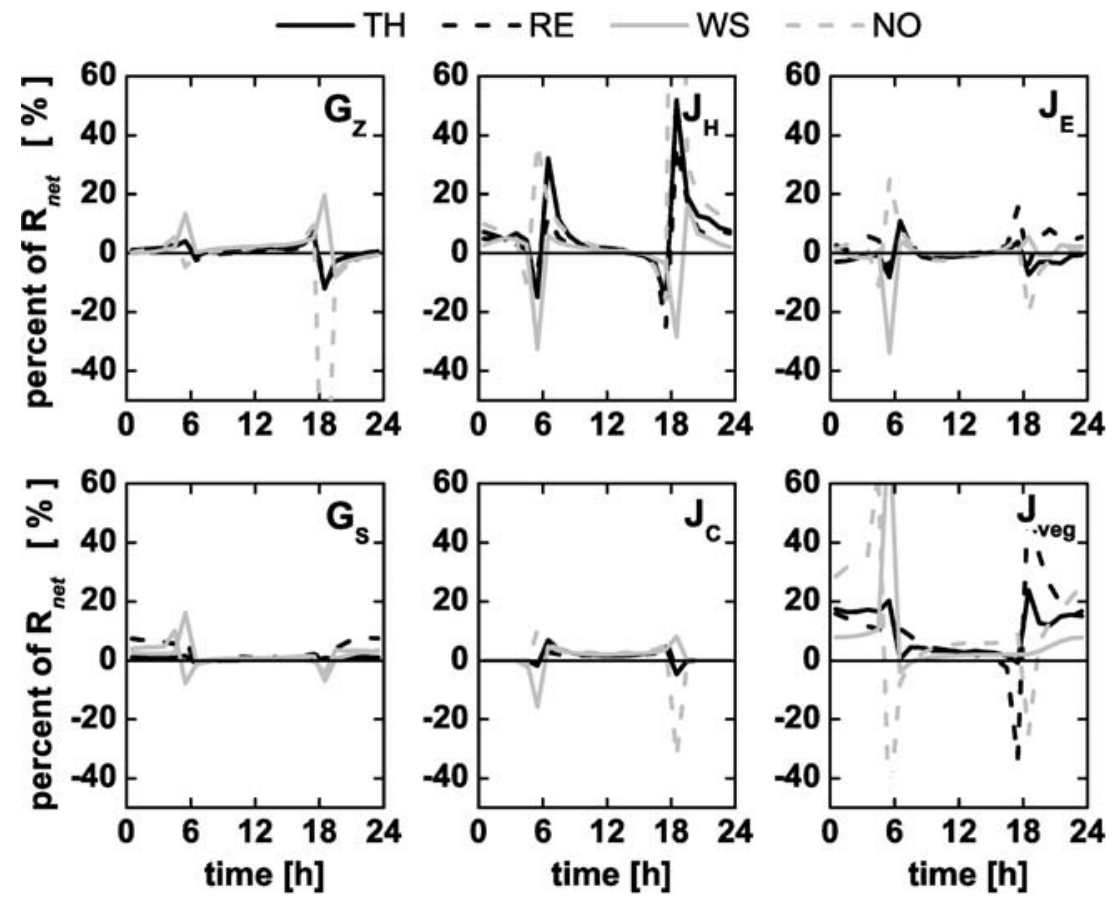

Fig. 3 Mean diurnal courses of relative size in relation to net radiation of $G_{Z}$ and of the storage terms $G_{\mathrm{S}}, J_{\mathrm{H}}, J_{\mathrm{E}}, J_{\mathrm{veg}}$ and $J_{\mathrm{C}}(1$-h averages) based on mean diurnal courses of the respective terms 
Table 4 Correlation coefficients and mean absolute differences of calculated sensible heat storage $J_{\mathrm{H}}$ and latent heat storage $J_{\mathrm{E}}$ between towers $\mathrm{A}, \mathrm{B}, \mathrm{C}$ and $\mathrm{D}$

Values in brackets refer to the differences between tower $\mathrm{D}$ and tower $\mathrm{A}, \mathrm{B}$, and $\mathrm{C}$, respectively (only Norunda)

${ }^{\text {a }}$ Absolute value of offset was always less than $1 \mathrm{~W} \mathrm{~m}^{-2}$

\begin{tabular}{|c|c|c|c|}
\hline & Ritten & Wetzstein & Norunda \\
\hline \multicolumn{4}{|l|}{$J_{\mathrm{H}}$} \\
\hline Correlation coefficient between towers & $\geq 0.81$ & $\geq 0.98$ & $\geq 0.98$ \\
\hline Slope of linear regression ${ }^{\mathrm{a}}$ (range) & $0.73-0.83$ & $0.94-1.00$ & $0.94-1.01$ \\
\hline Mean absolute difference $\left(\mathrm{W} \mathrm{m}^{-2}\right)$ & $<2.80$ & $<1.00$ & $<1.10$ \\
\hline $\begin{array}{l}\text { Percentage of absolute differences }<10 \quad \mathrm{~W} \mathrm{~m}^{-2}(\%) \\
J_{\mathrm{E}}\end{array}$ & $\geq 98.50$ & $\geq 99.00$ & $\geq 99.00$ \\
\hline Correlation coefficient between towers & $\geq 0.91$ & $\geq 0.96$ & $\geq 0.93(>0.82)$ \\
\hline Slope of linear regression ${ }^{\mathrm{a}}$ (range) & $0.86-0.99$ & $0.96-0.98$ & $0.86-0.98$ \\
\hline Mean absolute difference (W $\mathrm{m}^{-2}$ ) & $<3.4$ & $<1.1$ & $<2.4(<4.3)$ \\
\hline Percentage of absolute differences $<10 \mathrm{~W} \mathrm{~m} \mathrm{~m}^{-2}(\%)$ & $\geq 94.6$ & $>99.0$ & $\geq 93.0(>88.0)$ \\
\hline
\end{tabular}

4.3 Storage change in canopy air and biomass

\subsubsection{Sensible heat storage change $J_{H}$}

$J_{\mathrm{H}}$ was calculated separately for towers $\mathrm{A}, \mathrm{B}, \mathrm{C}$ and $\mathrm{D}$ of the ADVEX sites (RE, WS, NO). These independent estimates of the storage term $J_{\mathrm{H}}$ were in good agreement with each other at each site. This was reflected by the correlation coefficients and results of linear regressions (Table 4). The weaker correlation at RE can be ascribed to the greater heterogeneity of this site (very uneven aged stand with irregularly distributed gaps) in relation to the other sites. An investigation of the half-hourly differences between the storage estimates of the different towers also revealed good agreement (Table 4 and Fig. 4). Thus, storage change of sensible heat does not strongly depend on the placement of the tower within canopies with moderate heterogeneity. This suggests that storage change measured at the main tower of the $\mathrm{TH}$ site is also representative for the additional towers $\mathrm{P} 1, \mathrm{P} 2$ and $\mathrm{P} 3$ of MORE II.

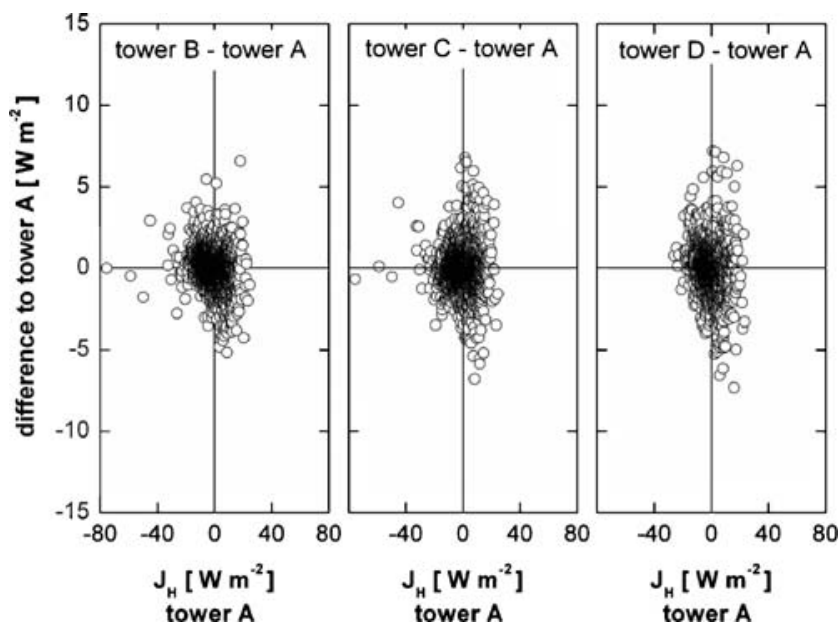

Fig. 4 Comparison of sensible heat storage term $J_{\mathrm{H}}$ (half-hourly differences), calculated for towers B, C, D in relation to tower A at Wetzstein
Mean diurnal patterns of $J_{\mathrm{H}}$ were similar at all sites with maximum positive values during the morning and maximum negative values in the evening (Fig. 2). Maximum positive values of the mean diurnal variation were slightly reduced if storage change was calculated using one layer only. This also holds for the maximum negative values in the evening but less strong. These results confirm the statement of Aston (1985) who noted that $J_{\mathrm{E}}$ and $J_{\mathrm{H}}$ may be underestimated if not the measurements of the full profile are used. However, mean values of both approaches were quite similar and differed by a maximal value of $0.01 \mathrm{~W} \mathrm{~m}^{-2}$ only.

Generally, the importance of $J_{\mathrm{H}}$ in relation to net radiation was small during day (approximately $<5 \%$ ) and higher at night (approximately 5-10\%). This behaviour was less pronounced for WS $(<6 \%)$ which might be due to the topography (ridge) and its ventilation of the canopy airspace.

\subsubsection{Latent heat storage change $J_{E}$}

Comparisons of latent heat storage at the towers A, B, C and D of the ADVEX sites (RE, WS, NO) yielded correlation coefficients slightly less than those for $J_{\mathrm{H}}$ (Table 4). Fairly good agreement was found between towers $\mathrm{A}, \mathrm{B}, \mathrm{C}$ and $\mathrm{D}$ at $\mathrm{RE}$ and $\mathrm{WS}$, but not in relation of $\mathrm{A}, \mathrm{B}, \mathrm{C}$ to tower $\mathrm{D}$ at NO. This might be due to the placement of tower $\mathrm{D}$, which was very close to a forest track. More pronounced heterogeneity may be one reason for the weaker correlation at RE (variable tree height, less dense canopy) and NO (rough ground with big stone blocks). Absolute mean differences between the towers are slightly higher as for $J_{\mathrm{H}}$ (Table 4; Fig. 5) indicating that half-hourly values might be more influenced by local conditions (wetness of local tower site).

$J_{\mathrm{E}}$ was found to be a very variable term. The highest values of $J_{\mathrm{E}}$ were sometimes associated with rain events. This result tends to support the findings of McCaughey and Saxton (1988) who stated that the magnitude of $J_{\mathrm{E}}$ might be also controlled by macroclimatic conditions. However, 


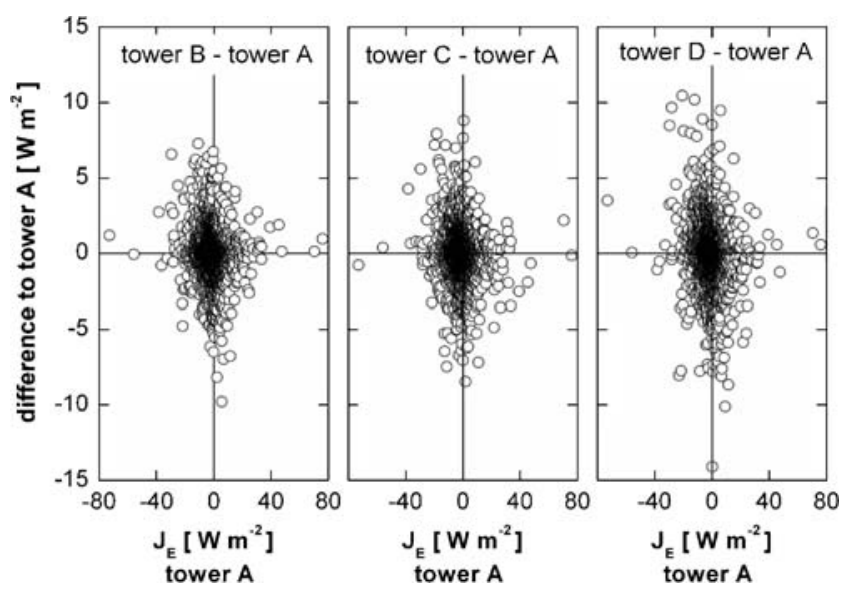

Fig. 5 Comparison of latent heat storage term $J_{\mathrm{E}}$ (half-hourly differences), calculated for towers B, C, D in relation to tower A at Wetzstein

when averaged over longer periods, maxima in the morning and the evening become visible which are separated by a local minimum (Fig. 2). Similar mean diurnal patterns are reported in Vogt et al. (1996) and Oliphant et al. (2004). Calculations using only the humidity measurement just above the canopy ( $z=30 \mathrm{~m}$ and $z=24 \mathrm{~m}$, respectively) decreased the maximum in the morning and increased the maximum in the evening for all sites slightly. These differences may be due to the fact that the change of humidity with time is more dampened within the canopy. However, main characteristics where not changed at all. As for $J_{\mathrm{H}}$, mean values of both approaches were quite similar (identical for TH, WS, RE), but differed by $0.06 \mathrm{~W} \mathrm{~m}^{-2}$ for Norunda, which might be explained by the general greater variability for $J_{\mathrm{E}}$ at this site.

During mid-day and in the afternoon, the ratio $J_{\mathrm{E}} / R_{\text {net }}$ was close to zero (Fig. 3). At night, this value was only slightly higher (approximately $<2-8 \%$ ).

\subsubsection{Biomass heat storage change $J_{v e g}$}

Biomass heat storage change $J_{\text {veg }}$ is characterised by a clear diurnal pattern (Fig. 2) with positive values during day (heat gain) and negative values during night (heat loss) and remarkable amplitudes between night and day. The largest amplitude showed NO, which has also the largest wet biomass. WS exhibited smallest amplitude as it experienced the smallest temperature changes of all investigated sites. This was also the case when temperatures measured near the centre of the bole were excluded.

When calculating $J_{\text {veg }}$ using $T_{\mathrm{a}}$ instead of $T_{\mathrm{veg}}$, the amplitude was clearly increased and the daily maximum was shifted towards the morning hours for all sites. Although mean values were of same magnitude, this change of diurnal pattern might influence the interpretation of the energy balance closure over day.

During night, the relative size of $J_{\text {veg }}$ in relation to $R_{\text {net }}$ was between $10 \%$ and $35 \%$ of $R_{\text {net }}$ whereas the biggest values were found for $\mathrm{NO}$ (largest wet biomass for all sites). During daytime, its relative size was not greater than $6 \%$.

\subsubsection{Biochemical heat storage change $J_{C}$}

This storage term is characterised by a clear diurnal pattern with maximum values during mid-day (Fig. 2). Maximum values coincided with maximum values of photosynthetic active radiation. Despite a different calculation approach, mean values during mid-day are comparable to or slightly larger than those given by Bernhofer et al. (2003) who found mean maximum storage values of $J_{\mathrm{C}}$ ranging from 2.5 to $7.4 \mathrm{~W} \mathrm{~m}^{-2}$ for some coniferous sites across Europe for July.

During daytime $J_{\mathrm{C}}$ had a relative size of approximately $1.5-3 \%$ of $R_{\text {net }}$ which was comparable to $J_{\mathrm{H}}$ and was surprisingly high. This may be due to the fact that most of the experimental periods were within the growing period resulting in higher values of $J_{\mathrm{C}}$. TH exhibits the smallest daily amplitude (Fig. 2) and also the smallest mean value (Table 5) of $J_{\mathrm{C}}$. This might due to the drought in 2003; however, the averaging period is longer than at the other sites and GPP is influenced by various factors.

\subsection{Available energy}

Ground heat flux $G$ as well as the sum of all storage terms $J$ depend largely on site characteristics but are typically small
Table 5 Mean values of the inspected components of available energy for each investigated site

Mean values are averages over the whole investigated period of each experiment as denoted in Table 1

\begin{tabular}{lrrrr}
\hline & Tharandt & Ritten & Wetzstein & Norunda \\
\hline$R_{\text {net }}\left(\mathrm{W} \mathrm{m}\right.$ m $\left.^{-2}\right)$ & 104.12 & 143.53 & 133.33 & 94.43 \\
$\left.G_{Z}(\mathrm{~W} \mathrm{~m})^{-2}\right)$ & 2.11 & 1.21 & 4.02 & 2.57 \\
$G_{\mathrm{S}}\left(\mathrm{W} \mathrm{m}\right.$ m $\left.^{-2}\right)$ & -0.01 & -0.03 & 0.11 & -0.05 \\
$G=G_{Z}+G_{\mathrm{S}}\left(\mathrm{W} \mathrm{m}{ }^{-2}\right)$ & 2.10 & 1.18 & 4.13 & 2.52 \\
$J_{\mathrm{H}}\left(\mathrm{W} \mathrm{m}\right.$ m $\left.^{-2}\right)$ & 0.03 & -0.05 & 0.04 & -0.03 \\
$J_{\mathrm{E}}\left(\mathrm{W} \mathrm{m}\right.$ m $\left.^{-2}\right)$ & -0.01 & -0.16 & 0.11 & 0.08 \\
$J_{\mathrm{veg}}\left(\mathrm{W} \mathrm{m}^{-2}\right)$ & -0.11 & -0.06 & 0.34 & -0.27 \\
$J_{\mathrm{C}}\left(\mathrm{W} \mathrm{m} m^{-2}\right)$ & 2.81 & 3.12 & 3.82 & 3.55 \\
\hline
\end{tabular}




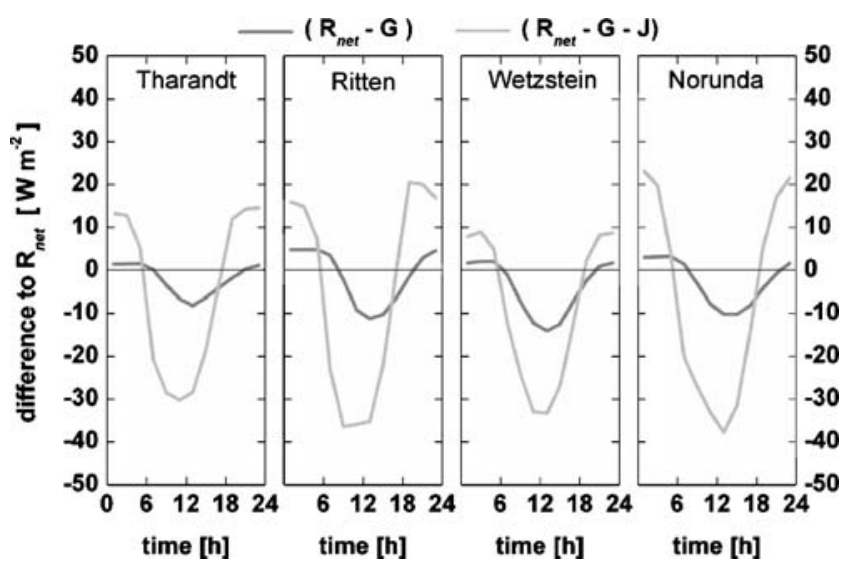

Fig. 6 Change of available energy if $G$ and $J$ were included calculated as differences $\left(R_{\text {net }}-G\right)-R_{\text {net }}$ and $\left(R_{\text {net }}-G-J\right)-R_{\text {net }}$, respectively, mean diurnal courses

compared to $R_{\text {net }}$. This was reflected by the mean values of the different terms of the available energy (Table 5). $G$ (sum of $G_{Z}$ and $G_{\mathrm{S}}$ ) was the second largest term at WS only, as $J_{\mathrm{C}}$ was the second largest term at $\mathrm{TH}, \mathrm{RE}$ and $\mathrm{NO}$ if averaged over the individual measurement period. $J_{\mathrm{C}}$ steadily contributed small positive values during daytime acting as a heat sink on average but is never negative (see Section 3.3.4) in contrast to $G$. Additional consideration of winter season will reduce this term as photosynthesis is reduced too. $J_{\mathrm{H}}, J_{\mathrm{E}}$ and $J_{\text {veg }}$ resulted in smaller mean values as the daily amplitude of these terms were quite large with almost similar contributions of negative and positive values (Fig. 2). Mean values of these terms can be negative or positive. This is due to different investigated periods and different meteorological conditions during the experiments. $J_{\mathrm{E}}$ was the smallest for TH as the year 2003 was a drought year. The mean value of $J_{\text {veg }}$ was the highest for Norunda (site with the highest above ground biomass). Remarkably, mean values of $J_{\mathrm{veg}}$ were higher than mean values of $J_{\mathrm{H}}$ for all sites indicating the relative importance of $J_{\mathrm{veg}}$.

Figure 6 shows how the diurnal cycle of available energy changed if not only $G$ but also $J$ was included for the determination of AE. The absolute amount of energy available for partitioning was reduced during day.

Despite different measurement years, as all experiments took place during the warmer season, the maximum values of the mean diurnal courses of AE during mid-day (Fig. 7) reflect the different latitudes of the sites with RE most south (the largest $\mathrm{AE}$ ) and $\mathrm{NO}$ most north (the smallest $\mathrm{AE}$ ), as $R_{\text {net }}$ (most important term of $\mathrm{AE}$ ) is mainly determined by latitude provided that the albedo do not differ too much.

Figure 7 also shows the mean diurnal courses of the estimated uncertainty in determining the available energy. The uncertainty of net radiation was estimated as stated in Section 4.1. The uncertainty of $J$ and $G$ was estimated to be $\pm 30 \%$ or $\pm 5 \mathrm{~W} \mathrm{~m}^{-2}$ whichever was the largest, following Vogt et al. (1996).

The absolute uncertainty of $\mathrm{AE}$ was largest during noon with mean absolute values of $44,52,49$ and $41 \mathrm{~W} \mathrm{~m}^{-2}$ (approximately $12 \%$ of $\mathrm{AE}$ ) for $\mathrm{TH}, \mathrm{RE}, \mathrm{WS}$ and $\mathrm{NO}$, respectively. Approximately $10 \mathrm{~W} \mathrm{~m}^{-2}$ of these mean absolute values were due to uncertainties in $J$ plus $G$. Vogt et al. (1996) stated a similar uncertainty up to $\pm 36 \mathrm{~W} \mathrm{~m}^{-2}$ (around mid-day) for the AE using corrected net radiation. The magnitudes of these absolute values indicate that the

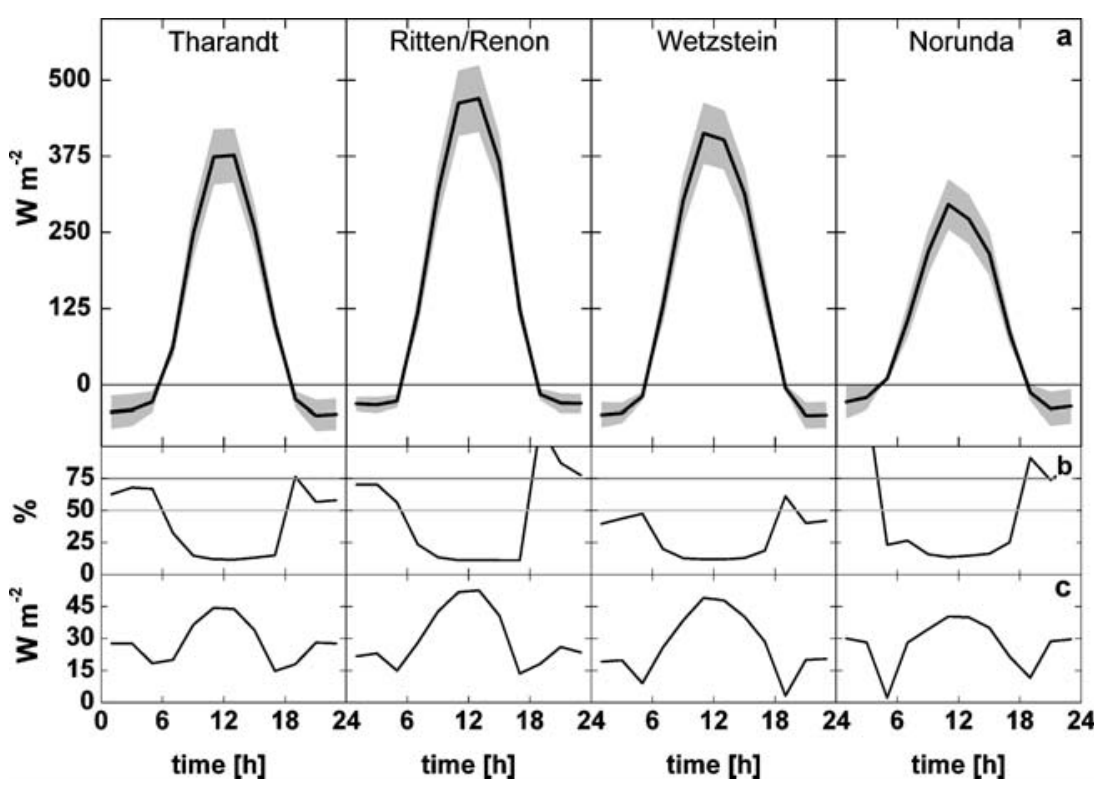

Fig. 7 Estimation of uncertainty incorporated in determining the available energy, a mean diurnal course of available energy (black line) and its upper and lower estimated uncertainty bound (grey area), b mean diurnal course of estimated relative uncertainty and $\mathbf{c}$ mean diurnal course of estimated absolute uncertainty 
Table 6 Systems used for assessing the turbulent fluxes of latent heat and sensible heat

\begin{tabular}{|c|c|c|c|c|}
\hline & Tharandt & Renon/Ritten & Wetzstein & Norunda \\
\hline Sonic anemometer & Gill R2 ${ }^{\mathrm{a}}$ & Gill $\mathrm{HS}^{\mathrm{a}}$ & Gill R3 $^{\mathrm{a}}$ & $\mathrm{USA}-1^{\mathrm{c}}$ \\
\hline Gas analyser & Li $6262^{\mathrm{b}}$ (closed path) & Li $7500^{\mathrm{b}}$ (open path) & Li $7500^{\mathrm{b}}$ (open path) & $\operatorname{Li} 7500^{\mathrm{b}}$ (open path) \\
\hline Height (m) & 42 & 32 & 30 & 33 \\
\hline
\end{tabular}

${ }^{\text {a }}$ Gill Instruments, UK

${ }^{\mathrm{b}}$ LiCor Inc., Lincoln, NE, USA

${ }^{\mathrm{c}}$ Metek GmbH, Germany

uncertainty in determining the available energy does not explain the lack of energy closure (at least during day) alone. At night, the absolute mean uncertainty was between 20 and $30 \mathrm{~W} \mathrm{~m}^{-2}$ for all sites and approximately $6 \mathrm{~W} \mathrm{~m}^{-2}$ of it were due to uncertainties in $J$ plus $G$. However, during nighttime, a great uncertainty remains as the available energy itself is small, which is reflected by the large relative uncertainty ranging from $35 \%$ to more than $100 \%$ (Fig. 7).

\subsection{Inspection of energy balance closure}

In the last step, the available energy was related to the sum of the turbulent fluxes of latent heat LE and sensible heat $H$. Used systems for estimating the turbulent fluxes of sensible heat and latent heat are listed in Table 6. For coordinate rotation, planar fit (Wilczak et al. 2001) was applied at WS, 2D rotation at $\mathrm{NO}$ and $\mathrm{RE}$ and 3D rotation at TH (Kaimal and Finnigan 1994; McMillen 1988). Buoyancy flux was converted to sensible heat flux following Schotanus et al. (1983) in order to account for influences of humidity and cross wind contamination. The latter one is only necessary if it has not been already done by the software of the sonic anemometer. Turbulent fluxes of latent heat were corrected for high frequency loss using a method similar to Eugster and Senn (1995) at TH. Turbulent fluxes of latent heat determined using open path systems (NO, RE, WS) were corrected for density fluctuations and vertical mass flow according to Webb et al.
(1980). For the inspection of energy balance closure, missing values, rainy periods and periods with relative humidity $>90 \%$ were excluded. Results are shown in Table 7 and Fig. 8. Generally, the slope of linear regression was increased and the offset reduced when storage terms were included. During periods of sufficient turbulent mixing (typically daytime), the energy balance closure was better than during periods of stable atmospheric stratification (typically nighttime). Overall, the slope of linear regression increased with increasing friction velocity $\left(u^{*}\right)$ indicating a better closure in relation to better turbulent mixing. However, RE showed a decrease in slope for $u^{*}>$ $1 \mathrm{~m} \mathrm{~s}^{-1}$ with values less than 1 and the slope was greater 1 for NO. This might be an effect of the low number of data pairs above this threshold (135 and 70 for RE and NO, respectively). The offset did not show any distinct behaviour with increasing $u^{*}$. The energy balance ratio (EBR) was calculated as follows:

$\mathrm{EBR}=\frac{\sum(H+\mathrm{LE})}{\sum(\mathrm{AE})}$

and increased when $J$ was included. Similar results are reported for different sites by, e.g. Aubinet et al. (2000), Grünwald and Bernhofer (2007) and Wilson et al. (2002). An investigation of Bowen's ratio $\beta$ ( $\beta=H / \mathrm{LE})$ revealed the largest value for TH (1.7), i.e. about two thirds more of the available energy was partitioned to sensible than to latent heat. RE, NO and WS showed smaller values of 1.2, 0.9

Table 7 Results of linear regression $\left(H+\right.$ LE) vs. $\left(R_{\text {net }}-G\right)$ and $\left(R_{\text {net }}-G-J\right)$, respectively, using half-hourly data

\begin{tabular}{|c|c|c|c|c|c|c|c|c|}
\hline & \multicolumn{4}{|c|}{$(H+$ LE $)$ vs. $\left(R_{\text {net }}-G\right)$} & \multicolumn{4}{|c|}{$(H+\mathrm{LE})$ vs. $\left(R_{\mathrm{net}}-G-J\right)$} \\
\hline & $R^{2}(-)$ & Slope $(-)$ & Offset $\left(\mathrm{Wm}^{-2}\right)$ & $\operatorname{EBR}(-)$ & $R^{2}(-)$ & Slope (-) & Offset $\left(\mathrm{Wm}^{-2}\right)$ & $\operatorname{EBR}(-)$ \\
\hline Tharandt & 0.92 & 0.75 & 21.851 & 0.95 & 0.92 & 0.81 & 18.59 & 0.98 \\
\hline Ritten & 0.79 & 0.96 & 58.56 & 1.22 & 0.81 & 1.02 & 47.37 & 1.24 \\
\hline Wetzstein & 0.92 & 0.67 & 16.04 & 0.77 & 0.92 & 0.70 & 14.94 & 0.80 \\
\hline Norunda & 0.90 & 0.90 & 32.73 & 1.09 & 0.90 & 1.00 & 24.99 & 1.16 \\
\hline
\end{tabular}

Missing values, rainy periods and periods with relative humidity $>90 \%$ were excluded

$E B R$ energy balance ratio 


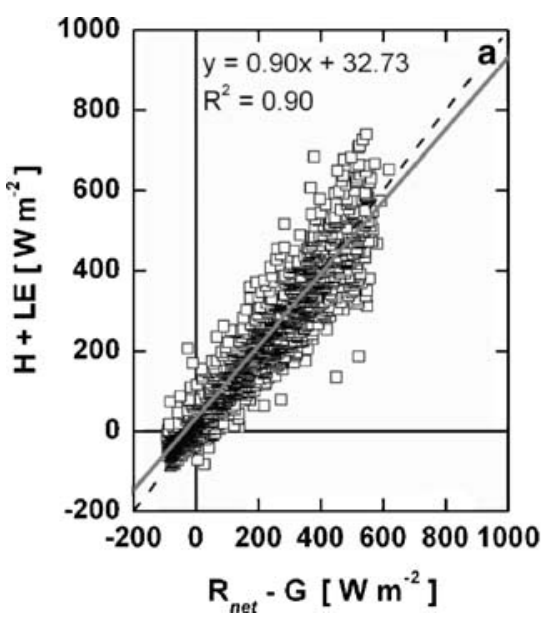

Fig. 8 Sum of latent heat LE and sensible heat $H$ vs. available energy, a $H+$ LE vs. $R_{\text {net }}-G$, b $H+$ LE vs. $R_{\text {net }}-G-J$ for NO (half-hourly data, missing values, rainy periods and periods with relative humidity

and 0.9 , respectively, and were (slightly) more than typical values stated in literature (e.g. Oke 1987). This suggests that the conditions tended to be dry at all sites during the different experimental periods, but were most dry at Tharandt (year 2003 - at least partly a drought year). No clear relationship between EBR and $\beta$ was found.

In Fig. 9, the diurnal course of the sum of the turbulent fluxes $H$ and LE is compared to the available energy with its estimated uncertainty bounds. Except for NO, absolute values of turbulent fluxes were mostly less than available energy during night. During daytime, results were different, ranging from very slightly $(\mathrm{TH})$ to pronounced underestimation (WS), slightly overestimation (RE) and almost perfect closure (NO). This indicates that the uncertainty of the available energy itself cannot always explain the difference between $H+\mathrm{LE}$ and the available energy, which

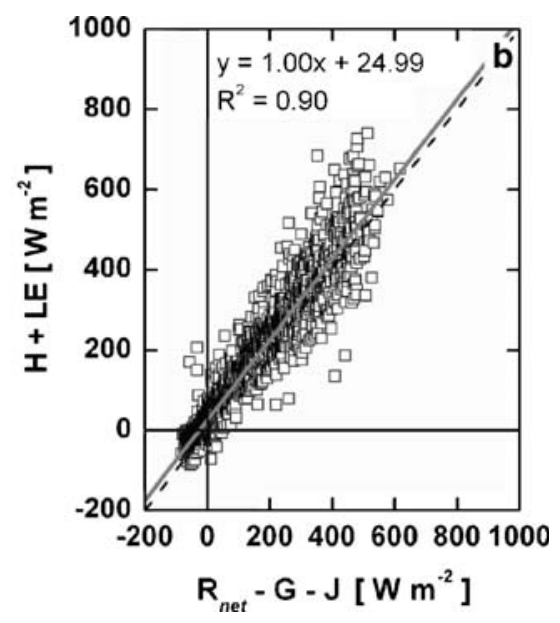

$>90 \%$ excluded). Thick black line denotes regression line. Dashed line denotes ratio 1

is in accordance with Foken (2008). When looking at Figs. 8 and 9, one can see that the turbulent fluxes exceed the available energy in case of RE and NO during noon. Additionally, an EBR greater than 1 was found for both sites. It is suspected that unaccounted processes might transport energy into the control volume and/or the chosen averaging interval does not capture all relevant frequencies, i.e. lower or higher frequencies are missed (e.g. Foken et al. 2006). However, turbulent fluxes of latent heat and sensible heat also bear uncertainties. Mauder et al. (2007b) pointed out that different post-field data processing methods and their order in post-field data processing process can cause differences up to $15 \%$ for fluxes of latent and sensible heat recorded with same system. A simple test was made and the turbulent fluxes were enlarged/reduced by $15 \%$ but this did not result in a closed energy balance.
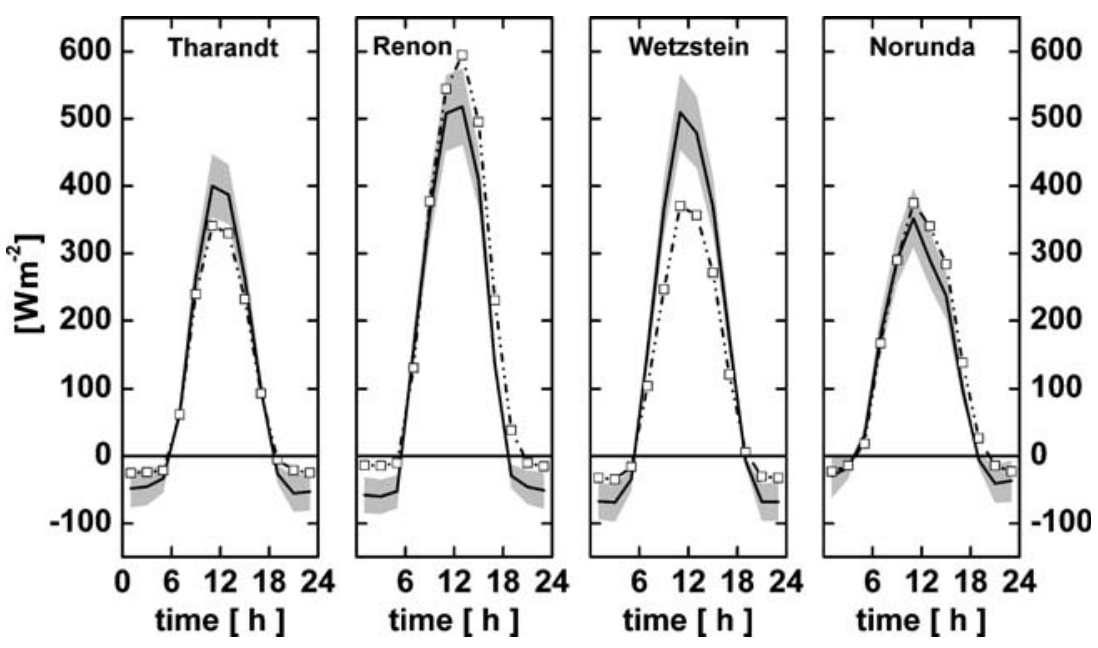

Fig. 9 Comparison of the mean diurnal course of available energy (black line) and its estimated uncertainty bounds (grey area) with the mean diurnal course of the sum of the turbulent fluxes $H$ and LE (dashed double dotted line with open squares) for each investigated site 
Processes (i.e. advection) not accounted for, in the data presented here, are suspected to cause the imbalance. However, also a more detailed calculation of $G_{\mathrm{S}}$ and $J_{\mathrm{veg}}$ could probably improve the energy balance closure. Here, the biomass storage and the phase shift between air, soil and biomass temperature deserve special attention.

\section{Summary and conclusions}

The available energy at four forest sites across Europe was estimated including the storage terms $J_{\mathrm{H}}, J_{\mathrm{E}}, J_{\mathrm{veg}}$ and $J_{\mathrm{C}}$.

Net radiation is the largest term of available energy and is the main driver of the turbulent fluxes. The performed checks on net radiation focussed on global radiation and did not reveal large errors concerning net radiation.

Single storage terms as well as their total were not only most important during night but also of some importance during day. The investigated storage terms $J$ did depend on different site characteristics such as structure of the canopy, biomass and moisture conditions during the experimental period. A comparison of the storage terms $J_{\mathrm{H}}$ and $J_{\mathrm{E}}$ calculated at different towers within a site showed good agreement indicating that storage change calculated at a single point is representative for the whole canopy at sites with sufficient homogeneity. During night, $J_{\text {veg }}$ was often the most important storage term in relation to net radiation. On average, $J_{\mathrm{C}}$ contributed small positive values (heat sink) to the available energy. Averaged over the whole period, it also reached values greater than $G$. This suggests that $J_{\text {veg }}$ and $J_{\mathrm{C}}$ should receive more attention in energy studies of tall canopies.

The estimated uncertainty bounds showed that the uncertainty in available energy cannot explain the lack of energy closure alone. Including $J$ in the available energy improved energy balance closure, but left up to $30 \%$ of the closure gap unexplained. Other causes like advection need to be investigated in this context.

Acknowledgements This work was funded by the Deutsche Forschungsgemeinschaft (Contract GZ: BE 1721/10-1). Data had been collected in the framework of the project VERTIKO funded by the Federal Ministry for Education and Research (BMBF), Germany (PT-UKF07ATF37) and in the framework of the project ADVEX of CarboEurope-Integrated Project of the European Commission (GOCE-CT2003-505572). We thank Fredrik Lagergren (Lund University, Sweden) for providing a huge amount of data and valuable information. The Department of Crop Production Ecology (Swedish University of Agricultural Sciences, Uppsala) is acknowledged for providing global radiation data of Ultuna. Two unknown reviewers are acknowledged for their comments that helped to improve the manuscript.

\section{References}

Anthoni PM, Knohl A, Rebmann C, Freibauer A, Mund M, Ziegler W, Kolle O, Schulze ED (2004) Forest and agricultural land-use dependent $\mathrm{CO}_{2}$ exchange in Thuringia, Germany. Glob Change Biol 10:2005-2019

Aston AR (1985) Heat storage in a young Eucalypt forest. Agric Forest Meteorol 35:281-297

Aubinet M (2008) Eddy covariance $\mathrm{CO}_{2}$ flux measurements in nocturnal conditions: an analysis of the problem. Ecol Appl 18:1368-1378

Aubinet M, Heinesch B, Yernaux M (2003) Horizontal and vertical $\mathrm{CO}_{2}$-advection in a sloping forest. Bound-Layer Meteorol 108:397-417

Aubinet M, Grelle A, Ibrom A, Rannik Ü, Moncrieff J, Foken T, Kowalski AS, Martin PH, Berbigier P, Bernhofer C, Clement R, Elbers J, Granier A, Grünwald T, Morgenstern K, Pilegaard K, Rebmann C, Snijders W, Valentini R, Vesala T (2000) Estimates of the annual net carbon and water exchange of forests: the EUROFLUX methodology. Adv Ecol Res 30:113-175

Baldocchi DD, Rao KS (1995) Intra-field variability of scalar flux densities across a transition between a desert and an irrigated potato field. Bound-Layer Meteorol 76:109-136

Baldocchi DD, Law BE, Anthoni PM (2000a) On measuring and modeling energy fluxes above the floor of a homogeneous and heterogeneous conifer forest. Agric Forest Meteorol 102:187-206

Baldocchi DD, Finnigan J, Wilson K, Paw U KT, Falge E (2000b) On measuring net ecosystem carbon exchange over tall vegetation on complex terrain. Bound-Layer Meteorol 96:257-291

Barr AG, King KM, Gillespie TJ, Den Hartog G, Neumann HH (1994) A comparison of Bowen ratio and eddy correlation sensible and latent heat flux measurements above a deciduous forest. Bound-Layer Meteorol 71:21-41

Barr AG, Morgenstern K, Black TA, McCaughey JH, Nesic Z (2006) Surface energy balance closure by the eddy-covariance method above three boreal forests stands and implications for the measurement of the $\mathrm{CO}_{2}$ flux. Agric Forest Meteorol 140:322-337

Bernhofer C (1992) Applying a simple three-dimensional eddy correlation system for latent and sensible heat flux to contrasting canopies. Theor Appl Climatol 46:163-172

Bernhofer C, Vogt R (1999) Energy balance closure gaps-a methodical problem of eddy covariance measurements? In: Proceedings of the international congress of biometeorology and international conference on urban climatology, 8-12 Nov, Sydney, Australia

Bernhofer C, Aubinet M, Clement R, Grelle A, Grünwald T, Ibrom A, Jarvis P, Rebmann C, Schulze ED, Tenhunen JD (2003) Spruce forests (Norway and Sitka spruce, including Douglas fir): carbon and water fluxes and balances, ecological and ecophysiological determinants. In: Valentini R (ed) Fluxes of carbon, energy and water of European forests. Ecol Stud 163. Springer, Berlin, pp 99-123

Blanford JH, Bernhofer C, Gay LW (1991) Energy flux mechanism over a pecan orchard oasis. In: Proceedings of the 20th Agric Forest Meteorol Conf, July 1991, Salt Lake City, Utah. American Meteorological Society, Boston

Blanken PD, Black TA, Yang PC, Neumann HH, Nesic Z, Staebler R, den Hartog G, Novak MD, Lee X (1997) Energy balance and canopy conductance of a boreal aspen forest: partitioning overstory and understory components. J Geophys Res 102:28915-28927

Blanken PD, Black TA, Neumann HH, Den Hartog G, Yang PC, Nesic Z, Staebler R, Chen W, Novak MD (1998) Turbulent flux 
measurements above and below the overstory of boreal aspen forest. Bound-Layer Meteorol 89:109-140

Brotzge JA, Duchon CE (2000) A field comparison among a domeless net radiometer, two four-component net radiometer, and a domed net radiometer. J Atmos Oceanic Technol 17:1569-1582

Duchon CE, Wilk GE (1994) Field comparison of direct and component measurements of net radiation under clear skies. J Appl Meteorol 33:245-251

Eugster W, Senn W (1995) A cospectral correction model for measurements of turbulent $\mathrm{NO}_{2}$ flux. Bound-Layer Meteorol $74: 321-340$

Feigenwinter C, Bernhofer C, Vogt R (2004) The influence of advection on short term $\mathrm{CO}_{2}$ budget in and above a forest canopy. Bound-Layer Meteorol 113:201-224

Feigenwinter C, Bernhofer C, Eichelmann U, Heinesch B, Hertel M, Janous D, Kolle O, Lagergren F, Lindroth A, Minerbi S, Moderow U, Mölder M, Montagnani L, Queck R, Rebmann C, Vestin P, Yernaux M, Zeri M, Ziegler W, Aubinet $M$ (2008) The ADVEX advection field campaigns: comparison of mean horizontal and vertical non turbulent advective fluxes at three CarboEurope forest sites. Agric Forest Meteorol 148: $12-24$

Field RT, Fritschen LJ, Kanemasu ET, Smith EA, Stewart JB, Verma SB, Kustas WP (1992) Calibration, comparison, and correction of net radiometer instruments used during FIFE. J Geophys Res 97:18681-18695

Finch JW, Harding RJ (1998) A comparison between reference transpiration and measurements of evaporation for a riparian grassland site. Hydrol Earth Syst Sci 2:129-136

Foken T (2008) The energy balance closure problem: an overview. Ecol Appl 18:1351-1367

Foken T, Wimmer F, Mauder M, Thomas C, Liebethal C (2006) Some aspects of the energy balance closure problem. Atmos Chem Phys 6:4395-4402

Garratt JR (1992) The atmospheric boundary layer. Cambridge University Press, New York, p 316

Gay LW, Vogt R, Kessler A (1996) The May-October energy budget of a Scots Pine plantation at Hartheim, Germany. Theor Appl Climatol 53:79-94

Goulden ML, Munger JW, Song-Miao F, Daube BC, Wofsy SC (1996) Measurements of carbon sequestration by long-term eddy covariance: methods and a critical evaluation of accuracy. Glob Change Biol 2:168-182

Grelle A, Lindroth A (1996) Eddy-correlation system for long-term monitoring of fluxes of heat, water vapour and $\mathrm{CO}_{2}$. Glob Change Biol 2:297-307

Grünwald T (2002) Langfristige Beobachtungen von Kohlendioxidflüssen mittels Eddy-Kovarianz-Technik über einem Altfichtenbestand im Tharandter Wald. Ph.D. thesis Technische Universität Dresden, Germany, p 124

Grünwald T, Bernhofer C (2007) A decade of carbon, water and energy flux measurements of an old spruce forest at the anchor station Tharandt. Tellus 59B:387-396

Gu LH, Meyers T, Pallardy SG, Hanson PJ, Yang B, Heuer M, Hosman KP, Liu Q, Riggs JS, Sluss D, Wullschleger SD (2007) Influences of biomass heat and biochemical energy storages on the land surface fluxes and radiative temperature. J Geophys Res. doi:10.1029/2006JD007425

Halldin S (2004) Radiation measurements in integrated terrestrial experiments. In: Kabat P, Claussen M, Dirmeyer PA, Gash JHC, de Guenni LB, Meybeck M, Pielke RA Sr, Vörösmarty CJ, Hutjes RWA, Lütkemeier S (eds) Vegetation, water, humans and the climate. A new perspective on an interactive system. Springer, Berlin, pp 167-171
Halldin S, Lindroth A (1992) Errors in net radiometry: comparison and evaluation of six radiometer designs. J Atmos Oceanic Technol 9:762-783

Heusinkveld BG, Jacobs AFG, Holtslag AAM, Berkowicz SM (2004) Surface energy balance closure in an arid region: role of soil heat flux. Agric Forest Meteorol 122:21-37

Jarvis PG, Massheder JM, Hale SE, Moncrieff JB, Rayment M, Scott SL (1997) Seasonal variation of carbon dioxide, water vapour and energy exchanges of a boreal black spruce forest. J Geophys Res 102:28953-28966

Kabat P, Hutjes RWA, Feddes RA (1997) Evaporation, sensible heat and canopy conductance of fallow savannah and patterned woodland in the Sahel. J Hydrol 188-189:494-515

Kaimal JC, Finnigan JJ (1994) Atmospheric boundary layer flows their structure and measurement. Oxford University Press, New York 289

Key J (2001) Streamer user's guide, cooperative institute for meteorological satellite studies. University of Wisconsin, Madison, p 96

Kohsiek W, Liebethal C, Foken T, Vogt R, Oncley SP, Bernhofer C, Debruin HAR (2007) The energy balance experiment EBEX2000. Part III: behaviour and quality of radiation measurements. Bound-Layer Meteorol 123:55-75

Laubach J (1996) Charakterisierung des turbulenten Austausches von Wärme, Wasserdampf und Kohlendioxid über niedriger Vegetation anhand von Eddy-Korrelations-Messungen. Band 3. Wissenschaftliche Mitteilungen aus dem Institut für Meteorologie der Universität Leipzig und dem Institut für Troposphärenforschung e.V, Leipzig, p 139

Lee X (1998) On micrometeorological observations of surface-air exchange over tall vegetation. Agric Forest Meteorol 91:39-49

Lee X, Hu X (2002) Forest-air fluxes of carbon, water and energy over non-flat terrain. Bound-Layer Meteorol 103:277-301

Liebethal C, Huwe B, Foken T (2005) Sensitivity analysis for two ground heat flux calculation approaches. Agric Forest Meteorol 132:253-262

Lundin LC, Halldin S, Lindroth A, Cienciala E, Grelle A, Hjelm P, Kellner E, Lundberg A, Mölder M, Morén AS, Nord T, Seibert J, Stähli M (1999) Continuous long-term measurements of soilplant atmosphere variables at a forest site. Agric Forest Meteorol 98-99:53-73

Malhi Y, Pegoraro E, Nobre AD, Pereira MGP, Grace J, Culf AD, Clement R (2002) The energy and water dynamics of a central Amazonian rain forest. J Geophys Res 107:8061. doi:10.1029/ 2001JD000623

Marcolla B, Cescatti A, Montagnani L, Manca G, Kerschbaumer G, Minerbi S (2005) Importance of advection in the atmospheric $\mathrm{CO}_{2}$ exchanges of an alpine forest. Agric Forest Meteorol 130:193-206

Mauder M, Jegede OO, Okogbue ED, Wimmer F, Foken T (2007a) Surface energy balance measurements at a tropical site in West Africa during the transition from dry to wet season. Theor Appl Climatol 89:171-183

Mauder M, Oncley SP, Vogt R, Weidinger T, Ribeiro L, Bernhofer C, Foken T, Kohsiek W, De Bruin HAR, Liu H (2007b) The energy balance experiment EBEX-2000. Part II: intercomparison of eddy-covariance sensors and post-field data processing methods. Bound-Layer Meteorol 123:29-54

Mayocchi CL, Bristow KL (1995) Soil surface heat flux: some general questions and comments on measurements. Agric Forest Meteorol 75:43-50

McCaughey JH (1985) Energy balance storage terms in mature mixed forest at Petawawa, Ontario - a case study. Bound-Layer Meteorol 31:89-101 
McCaughey JH, Saxton WL (1988) Energy balance storage terms in a mixed forest. Agric Forest Meteorol 44:1-18

McCaughey JH, Lafleur PM, Joiner DW, Bartlett PA, Costello AM, Jelinski DE, Ryan MG (1997) Magnitudes and seasonal pattern of energy, water and carbon exchanges at a boreal young jack pine forest in the BOREAS northern study area. J Geophys Res 102:28997-29008

McMillen TR (1988) An eddy correlation technique with extended applicability to non-simple terrain. Bound-Layer Meteorol 43:231-245

Meyers TP, Hollinger SE (2004) An assessment of storage terms in the surface energy balance of maize and soybean. Agric Forest Meteorol 125:105-115

Moderow U, Feigenwinter C, Bernhofer C (2007) Estimating the components of the sensible heat budget of a tall forest canopy in complex terrain. Bound-Layer Meteorol 123:99-123

Moore CJ, Fisch G (1986) Estimating heat storage in Amazonian tropical forest. Agric Forest Meteorol 38:147-169

Ochsner TE, Sauer TJ, Horton R (2007) Soil heat storage measurements in energy balance studies. Agron J 99:311-319

Oke TR (1987) Boundary layer climates, 2nd edn. Routledge, London, p 435

Oliphant AJ, Grimmond CSB, Zutter HN, Schmid HP, Su HB, Scott SL, Offerle B, Randolph JC, Ehman J (2004) Heat storage and energy balance fluxes for a temperate deciduous forest. Agric Forest Meterol 126:185-201

Oncley P, Foken T, Vogt R, Kohsiek W, DeBruin HAR, Bernhofer C, Christen A, van Gorsel E, Grantz D, Feigenwinter C, Lehner I, Liebethal C, Liu H, Mauder M, Pitacco A, Ribeiro L, Weidinger $T$ (2007) The energy balance experiment EBEX-2000. Part I: overview and energy balance. Bound-Layer Meteorol 123:1-28

Paw U KT, Baldocchi DD, Meyers TP, Wilson KB (2000) Correction of eddy-covariance measurements incorporation both advective effects and density fluxes. Bound-Layer Meteorol 97:487-511

Pilegaard K, Hummelshøj P, Jensen NO, Chen Z (2001) Two years of continuous $\mathrm{CO}_{2}$ eddy-flux measurements over a Danish beech forest. Agric Forest Meteorol 107:29-41

Reichstein M, Falge E, Baldocchi D, Papale D, Valentini R, Aubinet M, Berbigier P, Bernhofer C, Buchmann N, Gilmanov T, Granier A, Grünwald T, Havránková K, Janous D, Knohl A, Laurela T, Lohila A, Loustau D, Matteucci G, Meyers T, Miglietta F, Ourcival JM, Rambal S, Rotenberg E, Sanz M, Seufert G, Vaccari F, Vesala T, Yakir D (2005) On the separation of net ecosystem exchange into assimilation and ecosystem respiration: review and improved algorithm. Glob Change Biol 11:1-16

Richter G (1988) Stoffwechselphysiologie der Pflanzen, 5th edn. Georg Thieme, Stuttgart, p 639

Sauer TJ, Meek DW, Ochsner TE, Harris AR, Horton R (2003) Errors in heat flux measurements by flux plates of contrasting design and thermal conductivity. Vadose Zone J 2:580-588

Schotanus P, Nieuwstadt FTM, DeBruin HAR (1983) Temperature measurement with a sonic anemometer and its application to heat and moisture fluctuations. Bound-Layer Meteorol 26:81-93

Staebler RM, Fitzjarrald DR (2004) Observing subcanopy $\mathrm{CO}_{2}$ advection. Agric Forest Meteorol 122:139-156

Thom AS (1975) Momentum, mass and heat exchange of plant communities. In: Monteith JL (ed) Vegetation and the atmosphere 1. Academic, New York, pp 57-109

Twine TE, Kustas WP, Norman JM, Cook DR, Houser PR, Meyers TP, Prueger JH, Starks PJ, Wesely ML (2000) Correcting eddy covariance flux underestimates over a grassland. Agric Forest Meteorol 103:279-300

Valentini R, De Angelis P, Matteucci G, Monaco R, Dore S, Scarascia Mugnozza GE (1996) Seasonal net carbon dioxide exchange of a beech forest with the atmosphere. Glob Change Biol 2:199-207

Valentini R (ed) (2003) Fluxes of carbon, water and energy of European forests, Ecol Stud, vol 123. Springer, Berlin, p 266

Vogt R (2000) Aspekte der Strahlungsbilanzmessung. In: Berichte des Meteorologischen Instiuts der Universität Freiburg, Freiburg, Band 5, 173-183

Vogt R, Bernhofer C, Gay LW, Jaeger L, Parlow E (1996) The available energy over a Scots pine plantation: what's up for partitioning? Theor Appl Climatol 53:23-31

Webb EK, Pearman GI, Leuning R (1980) Correction of the flux measurements for density effects due to heat and water vapour transfer. Quart J Roy Meteorol Soc 106:85-100

Wilczak JM, Oncley SP, Stage SA (2001) Sonic anemometer tilt correction algorithms. Bound-Layer Meteorol 99:127-150

Wilson K, Baldocchi D (2000) Seasonal and interannual variability of energy fluxes over a broadleaved temperate deciduous forest in North America. Agric Forest Meteorol 100:1-18

Wilson K, Goldstein A, Falge E, Aubinet M, Baldocchi D, Berbigier P, Bernhofer C, Ceulemanns R, Dolman H, Field C, Grelle A, Ibrom A, Law BE, Kowalski A, Meyers T, Moncrieff J, Monson R, Oechel W, Tenhunen J, Valentini R, Verma S (2002) Energy balance closure at FLUXNET sites. Agric Forest Meteorol 113:223-243 